\title{
Identifying Critical Factors Contributing to Successful Innovations: A Pilot Study from Service Sector of Pakistan
}

\author{
Mohammad Waqas Raja ${ }^{1}$, Song Wei ${ }^{1} \&$ Ghulam Nabi ${ }^{1}$ \\ ${ }^{1}$ School of Public Affairs, University of Science and Technology of China, China \\ Correspondence: Mohammad Waqas Raja, School of Public Affairs, University of Science and Technology of \\ China, China. E-mail: mwaqasraja@hotmail.com
}

Received: April 1, 2015

doi:10.5539/ijbm.v10n7p120

\author{
Accepted: May 6, 2015 \\ Online Published: June 20, 2015 \\ URL: http://dx.doi.org/10.5539/ijbm.v10n7p120
}

\begin{abstract}
The study is a pilot investigation of the critical factors that are contributing to successful innovations in the service sector in Pakistan. The study dependent variable is innovation performance which has been divided into four main dimensions that are service innovations, process innovations, organization innovations, and marketing innovations while the independent variables are human capital, acquisition of knowledge, information sources for innovations and cooperation for innovation, and the moderating variables are size of firm in term of number of employees and budget for innovation. The data was collected using the modified CIS (community innovation survey) questionnaire which is mostly used by most European countries to access the innovation performance of firm. A sample of 127 firms was taken from different service firms from banking, software development, health, telecommunication firms. The study has firstly used descriptive analysis to explain the characteristics of sample then different inferential statistics are used to check the hypothesis developed for the study. The reliability, validity, internal consistency and internal correlation of items in the CIS was checked by using values of Cronbch's Alpha values and KMO values for factor analysis. The study has used the Tobit regression model and the results have shown the $\mathrm{P}$ value of human capital and information sources are significant for service innovations and the value for cooperation for innovation is significant for process innovations while human capital and cooperation for innovation had significant $\mathrm{p}$ values at 5 percent significance level for organizational innovations and acquisition of knowledge and information sources have significant $p$ value for marketing innovations. And the value for budget for innovation is significant for firm's organizational innovations.
\end{abstract}

Keywords: innovation, services, performance

\section{Introduction}

Services and innovations have characterized the recent growth of world economies, the service sector and innovation is emerging as a research area with an increasing importance and reference to economies especially the developing and under developed economies but many researchers (Sanchez, 2010; Castro et al., 2011; Crevani et al., 2011). Suggested that most researchers have concentrated their efforts on tangible product innovations which is more applicable to the manufacturing sector so there is a lot of room for contribution in the area of service innovations. As according to the inversion perspective of innovation services are in itself a source of innovation in other sectors especially in the manufacturing sector so from this perspective the importance of conducting research about innovations in service sector becomes even more important as these innovations can be treated as high tech innovations. (Czarnitzski \& Spielkamp, 2009) says services are becoming more and more innovative then imagined as compared to the manufacturing sector innovations average OECD (2005) and playing multivariate role in economies similarly in all world economies the share of services is increasing every year in the GDP especially related to those in the high tech sector. Another important trend in service sector is that the services and products are becoming merged with each other and the intangible and tangible difference is becoming smaller and smaller so there is a strong need to conduct further studies in the area of service innovations especially with reference to developing countries. So the research question for this study is "what are the critical factors that are contributing to successful innovations in the service sector in Pakistan" as this area of research is quite under researched so there is still room to contribute in this area and many unique characteristics and factors of service sector innovations can be identified especially with reference to developing country service innovations. 


\subsection{Different Theories and Paradigms of Innovation in Service Sector}

This study includes various theories and paradigms for innovation in the service sector and these theories and paradigm serves as basis for the identification of important variables affecting service sector innovations.

\subsection{Strategic Innovation Paradigm}

States innovations are market driven and they are affected by the strategic actions of service firms. Strategy works as an inspiration for innovation to know the desires of customers and internal available resources, in strategic innovations market demand is customer demand, competition, market possibilities and ideas for innovation comes from both internal and external sources.

\subsection{Social Capital Theory of Innovation}

The theory states that relationships between actors add value by increasing speed and efficiency of information process and new knowledge development in term of innovations and inventions. The factors of social capital include past experience, competitors action, customer feedback, internal firm social network, suppliers interactions etc. the social capital networks have many strategic benefits and it provide opportunities for timely access to information for innovations and it also builds a cooperative culture of mutual trust among members of service firms.

\subsection{Structure Conduct Performance Paradigm}

In this paradigm structure refers to the market structure which is mostly beyond the control of the firm for example industry concentration, market regulations, competition, entry and exit conditions while conduct refers to the behavior of the firm such as its actions toward innovations both inside and outside the firm and performance which is affected by both firms conduct and market structure.

\subsection{Market Pull Theory}

According to this theory consumer demand is a very important factor that forces the service sector firms to offer more innovative and consumer based innovations to survive in the competitive market. Now a day's more and firms are trying to fulfill there consumer's demands by providing more innovative services using consumer feedbacks and other techniques.

\subsection{Findings from the Literature}

According to Vermeulen et al. (2005) If we consider that the delivery of many services are based on people and their knowledge it is natural that human capital and knowledge emerge as important and crucial factors of innovation in services. Moreover, the training of employees is very important for service companies, especially those that are in direct contact with the client and it also affects the innovative capacity of firms. Pires et al. (2008) however, focuses on Portuguese service companies and said that the training of human resources has a significantly less impact on innovation in the service sector both in product and in process compared to the industrial companies, while the level of formal education of human resources has a significantly greater impact on product innovation, but significantly less in process innovation. Pires (2008) also concludes that company size can be considered an important determinant because while the larger companies provide the necessary resources to promote innovation and are less exposed to risk of failure thereof, small companies have more flexible and less paper-sapping management structures that benefit innovation, so the effects whirl in opposite directions.

Researchers like Schmidt and Rammer (2006), who evaluate separately a group of companies that demonstrate organizational innovation and marketing innovation. And found that the internal R\&D activities have no statistical relevance for both types of innovation, the external R\&D activities and the purchase of machinery, equipment and software are positively significant only to the organizational type of innovation and only the purchase of another type of external knowledge is positively and significantly related to both marketing innovation and organizational innovation. While Gomes et al. (2011) said companies have in the last few years shifted their focus of innovation from internal sources of information for example level of schooling of employees to external sources, such as consumers, universities, suppliers and business partners.

According to Camacho and Rodriguez (2005) the cooperation between companies and between these and other partners such as clients, suppliers, universities and research institutes have also been the focus of attention because cooperation is key to success in the innovative process, due to the extreme complex environment and the demand for knowledge, which increases in quantity and specificity. While according to Arvanitis and Bolli (2012), the participation in cooperation activities, in particular international cooperation, tends to have a positive effect on the innovation of companies because, the motivation underlying international cooperation features are 
associated with knowledge because of the greater likelihood of finding, abroad, highly technologically skilled partners than within a single country. Moreover such reasons seem to be more focused on finding a stronger innovative performance rather than on cost savings, which tends to benefit global corporate efficiency gains. Droege (2009) finds that higher R\&D investment is associated with more incremental innovation in Korean manufacturing industries.

\subsection{Service Sector in Pakistan}

The services sector is the largest and fastest growing sector in the world economy, accounting for the largest share in total output and employment in most developed countries. The average share of the services sector in total GDP is $47 \%$ in low income countries, $53 \%$ in middle income countries and $73 \%$ in high income countries.

The Pakistan economy has experienced significant changes. An analysis shows that the share of agriculture has been declining gradually over time from $43.6 \%$ in $1960-1961$ to $21.5 \%$ of GDP in 2009-2010, and share of industry has increased from $15.6 \%$ in $1960-1961$ to $25.2 \%$ of GDP in 2009-2010. The share of service sector has increased from $39 \%$ of GDP in $1960-1961$ to $53.3 \%$ of GDP in 2009-2010, therefore the service sector is the largest contributor to the GDP of Pakistan. Services sector contribution to Gross Domestic Product (GDP) at current price increased by one per cent to 54.4 per cent in 2011-2012, while in terms of value it contributed an additional Rs1.44 trillion to the economy, bringing the total contribution to Rs10.571 trillion, according to the State Bank of Pakistan data. In case of Pakistan, the share of services is increasing in all sectors of the economy. In fact, the growth rate of services sector is higher than the growth rate of agriculture and the industrial sector and it now accounts for one third of total employment. It also provides essential inputs to the agriculture sector and the manufacturing sector.

\subsection{Objectives of Study}

- The study has identified the key factors that contribute to the successful innovations in the service sector.

- The study has discussed in detail the previous work done by different researchers in area of service innovations and their results.

- The study had further categorized innovations into four forms in the service sector.

- The study had developed a comprehensive model to explain the effect of various independent variables (key factors) on the dependent variable (successful innovations).

\subsection{Variables of Study}

The dependent variable of this study is firm innovation. Which is further divided into four types.

- $\quad$ A Service innovation is the market introduction of a new or significantly improved service with respect to its capabilities, user friendliness, components or sub-systems.

- $\quad$ A Process innovation is the implementation of a new or significantly improved production process, distribution method, or supporting activity. Process innovations must be new to your enterprise, but they do not need to be new to your market.

- An Organisational Innovation is a new organisational method in your enterprise's business practices (including knowledge management), workplace organisation or external relations that has not been previously used by your enterprise. It must be the result of strategic decisions taken by management. It excludes mergers or acquisitions, even if for the first time.

- A Marketing Innovation is the implementation of a new marketing concept or strategy that differs significantly from your enterprise's existing marketing methods and which has not been used before. It requires significant changes in product design or packaging, product placement, product promotion or pricing.

\subsection{The Independent Variables}

This study has the following four independent variables that directly affect firms innovation practices in service sector firms.

\subsection{Human Capital}

The human capital includes the education, skills and training of employees of the service firm. Pires et al. (2008), Wong (2009), suggested that the education and training of human resources has a significantly less impact on innovation in the service sector.

\section{H1: Human capital is positively and significantly associated with innovation.}

- H1.1: Human Capital is positively and significantly associated with service innovation. 
- H1.2: Human capital is positively and significantly associated with process innovation.

- H1.3: Human Capital is positively and significantly associated with marketing innovation.

- H1.4: Human capital is positively and significantly associated with organizational innovation.

\subsection{Knowledge Capital}

The acquisition of knowledge and the activities thereof (such as R\&D, training and the purchase of machinery, equipment and software) have a positive effect on the companies' ability to innovate. Moreira et al. (2012), state that the internal R\&D activities, the purchase of machinery and software, and the acquisition of other types of external knowledge are positively and significantly related with marketing innovation.

\section{H2: Knowledge-sourcing activities are positively and significantly associated with innovation.}

- H2.1: Knowledge-sourcing activities are positively and significantly associated with service innovation.

- H2.2: Knowledge-sourcing activities are positively and significantly associated with process innovation.

- H2.3: Knowledge-sourcing activities are positively and significantly associated with marketing innovation.

- H2.4: Knowledge-sourcing activities are positively and significantly associated with organizational innovation.

\subsection{Information Sources}

Scholars in the field of innovation have focused on deepening the knowledge on how information is acquired and subsequently converted into innovation. Gomes et al. (2011), companies have, in the last few years, shifted their focus of innovation from internal sources of information to external sources, such as consumers, universities, conferences \& seminars.

H3: The use of universities, competitors, conferences as information source is positively associated with innovation.

- H3.1: Information Sources are positively and significantly associated with service innovation.

- H3.2: Information Sources are positively and significantly associated with process innovation.

- H3.3: Information Sources are positively and significantly associated with marketing innovation.

- H3.4: Information Sources are positively and significantly associated with organizational innovation.

\subsection{Cooperation for Innovation}

The cooperation between companies and between these and other partners (such as clients, suppliers, universities and research institutes) have been the focus of attention because cooperation is key to success to innovative. Hsueh et al. (2010) analysed a set of software B2B companies and concluded that cooperation with suppliers and clients was positively and significantly related with the innovative performance of the companies, whereas cooperation with research institutes showed no significant relationship.

\section{H4: The degree of cooperation for innovation with foreign entities is positively associated with innovation.}

- H3.1: Degree of cooperation for innovation is positively and significantly associated with service innovation.

- H3.2: Degree of cooperation for innovation is positively and significantly associated with process innovation.

- H3.3: Degree of cooperation for innovation is positively and significantly associated with marketing innovation.

- H3.4: Degree of cooperation for innovation is positively and significantly associated with organizational innovation.

\subsection{Moderating Variables}

These are the variables that modify the relationship between the dependent and independent variable. In this study we have two very important moderating variables in the theoretical framework.

\subsubsection{Size of Firm}

Some studies like Pires (2008) found that small firms are considerably less innovative then large service firms.

H5: Large service firms are more innovative then small firms. 


\subsubsection{Innovation Budget}

Droege (2009) says firms who fix separate innovation budget in strategic plan tend to be more innovative then firms who do not set innovation budgets.

H6: Firms with separate innovation budget are more innovative then firms with no separate budget for innovation.

\section{Methodology}

Convenience sampling technique is used to collect data for this pilot study. A total of 127 Questionnaires are filled from managers of various service firms from banking, software development, health, telecommunication area. The data is being collected using the modified CIS (community innovation survey) which is mostly used by most European countries to access the innovation performance of firm. The respondents are operations and quality assurance managers in different service firms. The details of sample are discussed in Table 1.

Table 1. Demographic profile of sample firms

\begin{tabular}{lll}
\hline Type of firms Service & Frequency & Percentage \\
\hline Banks & 28 & $23 \%$ \\
Hospitals & 25 & $20 \%$ \\
Universities & 17 & $13 \%$ \\
Telecommunication & 25 & $20 \%$ \\
Police/ law enforcement & 10 & $7 \%$ \\
Transport & 22 & $17 \%$ \\
Total & 127 & $100 \%$ \\
Area of Responsibility & Frequency & Percentage \\
Quality Assurance Managers & 47 & $37 \%$ \\
Operation Managers & 75 & $59 \%$ \\
Others & 5 & $4 \%$ \\
Total & 127 & $100 \%$ \\
Number Of Employees & Frequency & Percentage \\
$1000-3000$ & 0 & $0 \%$ \\
$3001-6000$ & 10 & $7 \%$ \\
$6001-9000$ & 20 & $16 \%$ \\
$9001-12000$ & 26 & $20 \%$ \\
$12001-$ More & 71 & $57 \%$ \\
Total & 127 & $100 \%$ \\
\hline
\end{tabular}

From Table 1 we can see that the total sample size is 127 out of which $23 \%$ are managers from banks, $20 \%$ from hospitals, $13 \%$ from universities, $20 \%$ from telecommunication, $7 \%$ from law enforcement, and $17 \%$ from transportation firms. In the sample $37 \%$ managers are from quality assurance and $59 \%$ are from operations department while the size of the firm is divided into various categories and $7 \%$ firms have employees from 3000 to 6000 while $16 \%$ firms in the sample have employees from 6001 to $9000,20 \%$ firms have 9001 to 12000 employees and the rest of the $57 \%$ firms in the sample have more than 12000 employees.

To check the internal consistency of measurement items we have used Cronbach's alpha value, and its coefficient value should be above .7 in order for the scale to have internal consistency. As we can see from Table 2 the Cronbach's Alpha values lies between .705 to .882 which shows that the items for all the constructs have high internal consistency and their average inter scale correlation values are between .465 to .780 which shows that the items used to measure each construct are highly correlated and are reliable. 
Table 2. Reliability analysis of constructs for innovation types and critical factors for innovation

\begin{tabular}{llccc}
\hline S. No & \multicolumn{1}{c}{ Construct } & $\begin{array}{c}\text { No of } \\
\text { Items }\end{array}$ & Cronbach's Alpha & $\begin{array}{c}\text { Average inter } \\
\text { correlations }\end{array}$ \\
\hline 1 & Service innovation & 3 & .714 & .465 \\
2 & Process innovation & 4 & .706 & .642 \\
3 & Marketing innovation & 3 & .855 & .780 \\
4 & Organization innovation & 4 & .882 & .501 \\
5 & Human capital & 3 & .706 & .551 \\
6 & Knowledge Capital & 3 & .714 & .475 \\
7 & Cooperation for Innovation & 3 & .705 & .565 \\
8 & Information Sources & 3 & .794 & .707 \\
9 & Budget for Innovation & 3 & .740 & .501 \\
\hline
\end{tabular}

Table 3 explains factor analysis results for innovation types and critical success factors for innovations. As we know Factor analysis is used to show the strength of the inter correlation among the items and the factorability of data is also checked by the statistical test of Kaiser Meyer Olkins (KMO) index range from 0 to 1 with.6 suggested as the minimum value for a good factor analysis it shows which factor we should retain in our analysis and the factor loadings greater than. 6 on a factor indicate high convergent validity. From the table we can see that the KMO value for the service innovation is .679 which shows a higher level of convergent validity among the factors used for service innovations and the factor loadings for SI1, SI2, SI3 are .616, .757, .718 respectively which shows that inter item correlation is very high. And the KMO value for the process innovation is .700 which shows a higher level of convergent validity among the factors used for process innovations and the factor loadings for PI1, PI2, PI3, PI4 are .773, .626, .691, .631 respectively which shows that inter item correlation is very high, the KMO value for the marketing innovation is .702 which shows a higher level of convergent validity among the factors used for marketing innovations and the factor loadings for MI1, MI2, MI3 are $.691, .604, .665$ respectively which shows that inter item correlation is very high.

Table 3. Factor analysis for innovation types and critical factors for innovation

\begin{tabular}{|c|c|c|c|c|c|}
\hline \multirow[t]{2}{*}{ S.no } & \multirow{2}{*}{$\begin{array}{l}\text { Component } \\
\text { Service innovation }(\mathrm{SI})(\mathrm{KMO})=.679\end{array}$} & \multirow[t]{2}{*}{ Eigen value } & \multirow[t]{2}{*}{$\%$ of variance } & \multicolumn{2}{|c|}{ Component Matrix Retained } \\
\hline & & & & Item & Component \\
\hline 1 & & 2.46 & 49.3 & SI1 & .616 \\
\hline 2 & & 1.28 & 25.7 & SI2 & .757 \\
\hline \multirow[t]{2}{*}{3} & & .555 & 11.0 & SI3 & .718 \\
\hline & Process innovation $(\mathrm{PI})(\mathrm{KMO})=.700$ & & & Item & Component \\
\hline 1 & & .913 & 22.7 & PI1 & .773 \\
\hline 2 & & .991 & 19.82 & PI2 & .626 \\
\hline 3 & & .833 & 16.66 & PI3 & .691 \\
\hline \multirow[t]{2}{*}{4} & & .625 & 12.5 & PI4 & .631 \\
\hline & Marketing innovation(MI) (KMO) $=.702$ & & & Item & Component \\
\hline 1 & & 2.37 & 39.6 & MI1 & .691 \\
\hline 2 & & 1.12 & 18.7 & MI2 & .604 \\
\hline \multirow[t]{2}{*}{3} & & .907 & 15.1 & MI3 & .665 \\
\hline & Organization innovation $(\mathrm{OI})(\mathrm{KMO})=.780$ & & & Item & Component \\
\hline 1 & & 3.48 & 58.12 & OI1 & .729 \\
\hline 2 & & 1.06 & 17.7 & OI2 & .772 \\
\hline 3 & & .520 & 8.67 & OI3 & .727 \\
\hline \multirow[t]{2}{*}{4} & & .426 & 7.10 & OI4 & .682 \\
\hline & Human capital $(\mathrm{HC})(\mathrm{KMO})=.802$ & & & Item & Component \\
\hline 1 & & 3.89 & 64.9 & $\mathrm{HC} 1$ & .718 \\
\hline 2 & & .694 & 11.5 & $\mathrm{HC} 2$ & .790 \\
\hline 3 & & .557 & 9.28 & $\mathrm{HC} 3$ & .759 \\
\hline & Knowledge Capital (KC) $(\mathrm{KMO})=.788$ & & & Item & Component \\
\hline 1 & & .555 & 11.0 & $\mathrm{KC} 1$ & .708 \\
\hline 2 & & .335 & 7.00 & $\mathrm{KC} 2$ & .821 \\
\hline
\end{tabular}




\begin{tabular}{|c|c|c|c|c|c|}
\hline 3 & & .333 & 6.66 & $\mathrm{KC} 3$ & .838 \\
\hline & \multirow[t]{4}{*}{ Cooperation for Innovation $(\mathrm{CFI})(\mathrm{KMO})=.786$} & & & Item & Component \\
\hline 1 & & .833 & 16.65 & CFI1 & .693 \\
\hline 2 & & .625 & 12.5 & CFI2 & 631 \\
\hline 3 & & .411 & 8.21 & $\mathrm{CFI} 3$ & .619 \\
\hline & \multirow[t]{4}{*}{ Information Sources (IS) $(\mathrm{KMO})=.705$} & & & Item & Component \\
\hline 1 & & .675 & 11.2 & IS1 & .659 \\
\hline 2 & & .518 & 8.63 & IS2 & .797 \\
\hline 3 & & .395 & 6.57 & IS3 & 689 \\
\hline & \multirow[t]{4}{*}{ Budget for Innovation $(\mathrm{BFI})(\mathrm{KMO})=.771$} & & & Item & Component \\
\hline 1 & & .426 & 7.10 & BFI1 & .682 \\
\hline 2 & & .300 & 4.99 & BFI2 & .837 \\
\hline 3 & & .203 & 3.38 & $\mathrm{BFI} 3$ & .867 \\
\hline
\end{tabular}

The KMO value for the organizational innovation is .780 which shows a higher level of convergent validity among the factors used for organization innovations and the factor loadings for OI1, OI2, OI3,OI4 are $.729, .772, .727, .682$ respectively which shows that inter item correlation is very high. And the KMO value for the human capital is .802 which shows a higher level of convergent validity among the factors used for human capital and the factor loadings for $\mathrm{HC} 1, \mathrm{HC} 2, \mathrm{HC} 3$ are $.718, .790, .759$ respectively which shows that inter item correlation is very high. The KMO value for the knowledge capital is .788 which shows a higher level of convergent validity among the factors used for knowledge capital and the factor loadings for $\mathrm{KC} 1, \mathrm{KC} 2, \mathrm{KC} 3$ are $.708, .821, .838$ respectively which shows that inter item correlation is very high. The KMO value for the cooperation for innovationis .786 which shows a higher level of convergent validity among the factors used for cooperation for innovationand the factor loadings for CFI1, CFI2, CFI3 are .693, .631, .619 respectively which shows that inter item correlation is very high for these items. The KMO value for the information sources is .705 which shows a higher level of convergent validity among the factors used for information sources and the factor loadings for IS1, IS2, IS3 are $.659, .797, .689$ respectively which shows that inter item correlation is very high for these items. And finally the KMO value for the budget for innovation is .771 which shows a higher level of convergent validity among the factors used for budget for innovation and the factor loadings for BFI1, BFI2, $\mathrm{BFI} 3$ are $.682, .837, .867$ respectively which shows that inter item correlation is very high for these items.

Table 4 explains the Pearson correlation test between critical success factors and innovation from the results we can see that there is a strong correlation among the service innovation and other critical success factors like human capital, knowledge capital, cooperation for innovation, information sources and budget for innovation with correlation scores $.45, .55, .56, .64, .57$ respectively. While the process innovation had a strong positive correlation with all critical factors for innovation with correlation scores between .51 to .68 , it also had strong correlation with the firms organizational innovations with score of .41. Similarly marketing and organizational innovations have strong correlation with human capital, knowledge capital, cooperation for innovation, information sources and budget for innovation with correlation scores of .65, .59. .44,.65, 46 and $.78, .71, .79, .57, .53$ respectively showing significant correlations.

Table 4. Pearson correlation test between critical success factors and innovation types

\begin{tabular}{cccccccccc}
\hline & SI & PI & MI & OI & HC & KC & CI & IS & BI \\
\hline SI & 1 & & & & & & & & \\
PI & .28 & 1 & & & & & & & \\
MI & .38 & .20 & 1 & & & & & & \\
OI & .39 & $.41^{* *}$ & .36 & 1 & & & & & \\
HC & $.45^{* *}$ & $.63^{* *}$ & $.65^{* *}$ & $.78^{* *}$ & 1 & & & & \\
KC & $.55^{* *}$ & $.68^{* *}$ & $.59^{* *}$ & $.71^{* *}$ & $.33^{* *}$ & 1 & & & \\
CI & $.56^{* *}$ & $.66^{* *}$ & $.44^{* *}$ & $.79^{* *}$ & $.22^{* *}$ & .20 & 1 & & \\
IS & $.64^{* *}$ & $.51^{* *}$ & $.65^{* *}$ & $.57^{* *}$ & .10 & .22 & .34 & 1 & \\
BI & $.57^{* *}$ & $.67^{* *}$ & $.46^{* *}$ & $.53^{* *}$ & .25 & .17 & .15 & .59 & 1 \\
\hline
\end{tabular}

Note.**. Correlation is significant at the 0.01 level (2-tailed). 
Table 5 explains the estimation results from the log transformed Tobit regressions for the four types of innovation performance (service innovations, process innovations, marketing innovations, organizational innovations) in the service firms. As we can see from the table that the distribution of innovation performance has a corner solution response property for example there are 51 firms in the left censored which shows that in these firms service innovations account for all innovation performance in these firms while there are 11 firms which are right censored which shows that in these firms service innovation do not account for any innovation in these firms.

In case of process innovations there are 35 firms in the left censored showing innovation performance is strongly affected by process innovations in these firms while 22 firms are right censored which suggest that in these firms process innovation do not account for any part in these firms innovation performance.

For organizational innovations 57 firms are left censored showing strong effect of organizational innovations in innovation performance and 10 firms are right censored showing no effect of organizational innovations in the innovation performance of these service firms and finally for marketing innovations 37 firms are left censored showing strong effect of marketing innovations on innovation performance while 15 firms are right censored in marketing innovation showing that in these 15 firms there is no effect of marketing innovation in the innovation performance of these firms.

Table 5a. Tobit regression by innovation types

\begin{tabular}{clcccc}
\hline S.no & \multicolumn{1}{c}{ Variables } & Service innovation & Process innovation & Organization innovation & Marketing innovation \\
\hline $\mathbf{1}$ & Human Capital & $0.1762^{*}$ & 0.0221 & 0.0674 & $0.1451^{*}$ \\
$\mathbf{2}$ & Knowledge Capital & 0.0382 & 0.0491 & 0.0517 & 0.0609 \\
$\mathbf{3}$ & Cooperation for Innovation & 0.0274 & $2.1698^{*}$ & $2.9408^{*}$ & 0.0761 \\
$\mathbf{4}$ & Information Sources & 0.0607 & $1.3111^{*}$ & -0.0109 & $2.1698^{*}$ \\
$\mathbf{5}$ & Budget for Innovation & 0.0302 & -0.0124 & $1.9725^{* *}$ & 0.0720 \\
\hline
\end{tabular}

Table 5b. Dummies used in the study

\begin{tabular}{lcccc}
\hline Number & 127 & 127 & 127 & 127 \\
\hline Left censored Number & 51 & 35 & 57 & 37 \\
Right censored Number & 11 & 22 & 10 & 15 \\
Log likelihood & -404.5643 & -356.0902 & -518.9113 & -451.6223 \\
chi2 & 60.7709 & 33.0299 & 22.5512 & 31.8870 \\
Pseudo R2 & .0430 & .0351 & .0611 & .4901 \\
\hline
\end{tabular}

Note.* $\mathrm{p}<.1 ; * * \mathrm{p}<.05$.

From the Table 5 the coefficient for service innovations is .18 while the coefficient for marketing innovation is .14 which shows that the coefficient values for both service and marketing innovations are significant at 10 percent level for the human capital while for process innovation the coefficient value is .022 and for organizational innovations its value is .06 both values are insignificant these results resembles the finding of Wong (2009) where he proposes that training human resources significantly affects a firms innovation performance in the firms so our first hypothesis $\mathrm{H} 1$ is partially supported and we can accept our sub hypothesis H1.1 and H1.3 while the other two sub hypothesis H1.2 and H1.4 cannot be accepted. While for knowledge capital the coefficient values for service innovations, process innovations, organizational innovations and marketing innovations do not have significant values at 10 percent or 5 percent significance level so the results do not support our second hypothesis $\mathrm{H} 2$ that knowledge-sourcing activities are positively and significantly associated with innovation intern our all four sub hypothesis cannot be accepted.

The coefficient value for process innovation is 2.1 and for organization innovation its value is 2.9 both values are significant at 10 percent significance level these results show that cooperation for innovation significantly effects firms process and organizational innovations so our third hypothesis $\mathrm{H} 3$ is also partially supported by the results and we can accept our sub hypothesis H3.2 and H3.4 these finding resembles the results by Hsueh et al. (2010) who concluded that cooperation with suppliers and clients was positively and significantly related with the innovative performance of the companies.

The coefficient value for process innovation is 1.3 and for marketing innovation its value is 2.6 and both values 
are significant at 10 percent level of significance which shows that information sources like customer feedback, universities, conferences and seminars helps in the process and marketing innovation in these service firms these results are in line with the findings of Gomes (2011) while the values for service innovations and organizational innovations are insignificant and in this case $\mathrm{H} 4$ is also partially supported with the results and we can accept our sub hypothesis $\mathrm{H} 4.2$ and $\mathrm{H} 4.3$.

The coefficient value for organizational innovation is 1.9 at 5 percent confidence level which shows that a higher budget for innovation significantly effects organizational innovations in the selected service firms. These results are similar to the findings of Droege (2009) who concluded that there is a strong impact of investment in R\&D with the organizational innovation capabilities of the firms so $\mathrm{H} 6$ can be accepted based on the significant value for organizational innovations.

\section{Conclusion}

Based on the above analysis this study concludes that human capital like employee education and employee training for innovation has significant effect on enhancing firm's service innovation capacity as well as making its marketing innovation performance better. Similarly cooperation for innovation through suppliers, clients and universities have significant effect on process and organizational innovation practices of service firms and the these firms can introduce more process innovation as compared to those firm who do not cooperate with their clients and suppliers to introduce new processes and such firms can also introduce new organizational processes at a higher rate. Information sources for innovation like universities, conferences, seminars play important role in enhancing firm's process and marketing innovations because managers of these service firms can get new ideas and knowledge by attending these seminars and conferences and can introduce new marketing strategies and processes in their firms and finally a separate budget for innovation strongly effects the firm's organizational innovations as higher budget for innovation works as an incentive for the managers to implement new practices in their firms.

\section{References}

Arvanitis, S., \& Bolli, T. (2012). A Comparison of National and International Innovation Cooperation in Five European Countries. Review of Industrial Organization, 1-29.

Barras, R. (1986). Towards a theory of innovation in services. Research Policy, 15, 161-173. http://dx.doi.org/10.1016/0048-7333(86)90012-0

Camacho, J., \& Rodríguez, M. (2005). How innovative are services? An empirical analysis for Spain. The Service Industries Journal, 25(2), 253-271. http://dx.doi.org/10.1080/0264206042000305448

Castro, L. M., Montoro-Sanchez, A., \& Criado, M. O. (2011). Innovation in services industries: Current and future trends. The Service Industries Journal, 31(1), 7-20. http://dx.doi.org/10.1080/02642069.2010.485196

Chesbrough, H., \& Crowther, A. H. (2006). Beyond high tech: Early adopters of open innovation in other industries. $R \& D$ Management, 36(3), 229-236. http://dx.doi.org/10.1111/j.1467-9310.2006.00428.x

Crevani, L., Palm, K., \& Schilling, A. (2011). Innovation management in service firms: A research agenda. Service Business, 5, 177-193. http://dx.doi.org/10.1007/s11628-011-0109-7

Czarnitzki, D., \& Spielkamp, A. (2009). Business services in Germany: Bridges for innovation. The Service Industries Journal, 2(2), 1-30.

Droege, H., Hildebrand, D., \& Forcada, M. (2009). Innovation in services: present findings, and future pathways. Journal of Service Management, 20(2), 131-155. http://dx.doi.org/10.1108/09564230910952744

Edwards, T., Delbridge, R., \& Munday, M. (2005). Understanding innovation in small and medium-sized $\begin{array}{lllll}\text { enterprises: A } & \text { A }\end{array}$ http://dx.doi.org/10.1016/j.technovation.2004.04.005

Gallouj, F., \& Savona, M. (2009). Innovation in services: a review of the debate and a research agenda. Journal of Evolutionary Economics, 19(2), 149-172. http://dx.doi.org/10.1007/s00191-008-0126-4

Gómez, J., \& Murguia, C. (2010). Vínculos de cooperación como fuente de información para la innovación. Cuadernos de Administración, 23(41), 61-79.

Hsueh, J., Lin, N., \& Li, H. (2010). The effects of network embeddedness on service innovation performance. The Service Industries Journal, 30(10), 1723-1736. http://dx.doi.org/10.1080/02642060903100398

Kim, K., \& Youn, Y. (2010). An analysis of patterns and determinants of service companies' innovation in Korea. KDI Policy Research Series 2010-17. 
Kirner, E., Kindel, S., \& Jaeger, A. (2009). Innovation paths and the innovation performance of low technology firms: An empirical analysis of German industry. Research Policy, 38, 447-458. http://dx.doi.org/10.1016/j.respol.2008.10.011

Lee, C. W. (2007). Strategic alliances influence on small and medium firm performance. Journal of Business Research, 60, 731-741. http://dx.doi.org/10.1016/j.jbusres.2007.02.018

Lee, S., Park, G., Yoon, B., \& Park, J. (2010). Open innovation in SMEs: An intermediated network model. Research Policy, 39(2), 290-300. http://dx.doi.org/10.1016/j.respol.2009.12.009

Leiponen, A. (2006). Managing knowledge for innovation: The case of business-to-business services. Journal of Product Innovation Management, 23(3), 238-258. http://dx.doi.org/10.1111/j.1540-5885.2006.00196.x

Lhuillery, S., \& Pfister, E. (2009). R\&D cooperation and failures in innovation projects: Empirical evidence from French CIS data. Research Policy, 38, 45-57. http://dx.doi.org/10.1016/j.respol.2008.09.002

Lichtenthaler, U. (2008). Open innovation in practice: An analysis of strategic approaches to technology transactions. IEEE Transactions on Engineering Management, 55(1), 148-157. http://dx.doi.org/10.1109/TEM.2007.912932

Mairesse, J., \& Mohnen, P. (2002). Accounting for innovation and measuring innovativeness: An illustrative framework and an application. American Economic Review, 92(2), 226-230. http://dx.doi.org/10.1257/000282802320189302

Moreira, J., Silva, M. J., Simões, J., \& Sousa, G. (2012). Drivers of marketing innovation in Portuguese firms. The Amfiteatru Economic Journal, 14(31), 195-206.

OECD. (2005). Promoting innovation in services. Working party on innovation and technology policy. DSTI/STP/TIP(2004)4/ Final.

Pires, C., Sarkar, S., \& Carvalho, L. (2008). Innovation in services-how different from manufacturing? The Service Industries Journal, 28(10), 1339-1356. http://dx.doi.org/10.1080/02642060802317812

Sampson, R. C. (2007). R\&D alliances and firm performance: The impact of technological diversity and alliance organization on innovation. Academy of Management Journal, 50(2), 364-386. http://dx.doi.org/10.5465/AMJ.2007.24634443

Schmidt, T., \& Rammer, C. (2006). Sources of information and cooperation for innovation in Norway. Journal of International Business Research, 10(2), 91-102.

Shearmur, R., \& Doloreux, D. (2009). Place, Space and distance: Towards a geography of knowledge-intensive business services innovation. Industry and Innovation, 16(1), 79-102. http://dx.doi.org/10.1080/13662710902728001

Tether, B. (2002). Who co-operates for innovation, and why: An empirical study. Research Policy, 31, 947-967. http://dx.doi.org/10.1016/S0048-7333(01)00172-X

Tsai, K. H., \& Wang, J. C. (2008). External technology acquisition and firm performance: A longitudinal study. Journal of Business Venturing, 23, 91-112. http://dx.doi.org/10.1016/j.jbusvent.2005.07.002

Un, C., \& Montoro-Sanchez, A. (2010). Public funding for product, process and organizational innovation in service industries. The Service Industries Journal, 30(1), 133-147. http://dx.doi.org/10.1080/02642060802252035

Vermeulen, P., De Jong, J., \& O' Shaughnessy, K. (2005). Identifying key determinants for new product introductions and firms performance in small service firms. The Service Industries Journal, 25(5), 625-640. http://dx.doi.org/10.1080/02642060500100783

Wong, P. K. (2009). Knowledge interaction with manufacturing clients and innovation of knowledge-intensive business services firms. Innovation: Management, Policy and Practice, 11(3), 264-278. http://dx.doi.org/10.5172/impp.11.3.264

Zhang, A., Zhang, Y., \& Zhao, R. (2003). A study of the R\&D efficiency and productivity of Chinese firms. Journal of Comparative Economics, 31(3), 444-464. http://dx.doi.org/10.1016/S0147-5967(03)00055-6 


\section{Copyrights}

Copyright for this article is retained by the author(s), with first publication rights granted to the journal.

This is an open-access article distributed under the terms and conditions of the Creative Commons Attribution license (http://creativecommons.org/licenses/by/3.0/). 